\title{
ABSCOPAL EFFECT OF RADIOTHERAPY: AN OLD CONCEPT IN A NEW ERA
}

\author{
MARTINA MIKULANDRA ${ }^{1}$, IVA ANDRAŠEK ${ }^{1}$ and LIDIJA BEKETIĆ-OREŠKOVIĆc ${ }^{1,2}$ \\ ${ }^{1}$ Division of Radiotherapy and Medical Oncology, University Hospital for Tumors, \\ Sestre milosrdnice University Hospital Center, Zagreb, Croatia; \\ ${ }^{2}$ Department of Clinical Oncology, School of Medicine University of Zagreb, Zagreb, Croatia
}

\begin{abstract}
Summary
The abscopal effect is a phenomenon that describes the systemic antitumor response that can occur as a result of a localized radiotherapy. Although sporadic cases of abscopal effect have been reported since 1960's, the number of reported cases are significantly increasing in the immunotherapy era. Immunotherapy seems to enhance the immunogenic effects of radiotherapy, thus increasing systemic antitumor response. Although combination of radiotherapy and immunotherapy is a promising strategy in the treatment of metastatic cancers, many questions regarding the optimal treatment remain unanswered. Increasing number of ongoing studies will hopefully provide answers to these questions, enabling the utilization of this strategy in systemic anticancer treatment.
\end{abstract}

KEY WORDS: abscopal effect, radiotherapy, immunotherapy

\section{INTRODUCTION}

Ever since it was first introduced into the treatment of cancer, radiotherapy has been utilized predominantly in the local treatment of cancer. Its effects can be seen mainly within the irradiated volume, with seemingly no effect on the cells and tissues outside of the treated area. Because of this, radiotherapy has found its place in the primary, neoadjuvant and adjuvant treatment of many sites of localized cancers, as well as palliative treatment of cancer metastases.

Lately, based on a series of case reports and further prompted by promising results of preclinical and clinical studies, a new question has risen:

Corresponding author: Lidija Beketić-Orešković, Department of Clinical Oncology, School of Medicine University of Zagreb and Division of Radiotherapy and Medical Oncology, University Hospital for Tumors, Sestre milosrdnice University Hospital Center, Ilica 197, Zagreb, Croatia.

e-mail: lidijabeketicoreskovic@gmail.com can radiotherapy be used not only for locoregional treatment, but as an active treatment of metastatic disease?

In 1953. Mole was first to use the word $a b$ scopal. He defined it as at a distance from the irradiated volume, but within the same organism (1). The word itself is derived from the Latin prefix $a b$, which means away from, and Greek word scopus, which means target. Essentially, the term abscopal effect refers to an effect of certain treatment occurring outside of the treatment field. Over the course of the last sixty years, number of case reports described regression and even disappearance of distant metastases following radiation treatments of a single site. While cases varied in patient age, gender and tumor biology, it was clear that abscopal effect occurred mainly in immunogenic tumors, such as melanoma, renal cell carcinoma, lung adenocarcinoma, lymphomas and leukemias (2). All of these tumors are known to have high T-cell infiltration scores. 
The recent years have brought rapid development of immunotherapy (reviewed in 3,4). New drugs which modulate the immune system are progressively used not only in immunogenic tumors, such as melanoma (5), but also in lung cancer (6), esophageal, gastric and even colorectal cancer (7). It should be noted that head and neck squamous cell cancer, cervical cancer, colorectal cancer, and lung squamous cell cancer are also cancers with high T-cell infiltration scores, which suggests the possibility of efficacy of combined immunotherapy and radiotherapy treatment.

This has once again brought light on the abscopal effect, prompting questions whether immunotherapy can potentially trigger abscopal effect of radiotherapy.

\section{THE MECHANISM OF ABSCOPAL EFFECT}

Radiation induces cell death via a specific process known as immunogenic cell death. During this process a number of immunogenic factors, such as DAMPs (damage-associated molecular patterns), are released. DAMPs include ATP (adenosine triphosphate), HMGB1 (high mobility group box 1) protein and calreticulin [8]. More specifically, during immunogenic cell death calreticulin is translocated to the cell surface, where is recognized and processed by dendritic cells (DCs). Mature DCs present tumor antigens to cytotoxic $\mathrm{T}$ lymphocytes (CTLs) and activate systemic antitumor response (9). HMBG1 binds to Toll-like receptor 4 (TLR4) on the surface of DCs, thus increasing antigen presentation (10). ATP can also bind on receptors on DCs, which results in interleukin $1 \beta$ release (11). In addition to that, nucleic acids released from dead cells can act as ligands to Toll-like receptors (TLR3, 7, 8 and 9), which results in the release of various cytokines and interferons, and also enhances DC cross-priming (12).

Radiation also causes the upregulation of Fas molecule, a known trigger of apoptosis, as well as MHC I (major histocompatibility complex) complex, thus additionally increasing antigen presentation to the cytotoxic T lymphocytes ) $(2,13)$.

It has been shown that the activation of cytotoxic T lymphocytes is a marker of radiosensitivity (14), and is a key in the development of the abscopal effect (15).

Abscopal effect in clinical setting is a very rare event. This is probably due to the fact that ra- diation can exhibit immunosuppressive effects, mainly through upregulation of TGF $\beta$ (transforming growth factor beta), enhancement of regulatory T-cell representation, and recruitment of myeloidderived suppressor cells (16-19). These immunosuppressive effects in most cases likely counteract the immunostimulatory effects, which results in rarity of the abscopal effect.

However, the emergence and rapidly growing use of immunotherapy has brought into focus the potential of radiation therapy to induce systemic antitumor responses, by tipping the scale in favor of immunostimulatory, rather than immunosuppressive effects of radiation.

\section{CLINICAL EVIDENCE OF THE ABSCOPAL EFFECT}

In 2019 Dagoglu et al. published a systematic review of the reported cases of abscopal effect (disregarding the articles where current cytotoxic treatment was given with radiotherapy) between 1960 and November 2018 and found 94 reported cases in 52 articles. It is notable that half of the reported cases were treated with radiotherapy only, and were reported between 1969 and 2018, while the other half of the cases were treated with a combination of radiotherapy and immunotherapy and reported between 2012 and 2018. The majority of the latter subgroup of patients were treated for non-small cell lung cancer and melanoma, while the other included Hodgkin's lymphoma, gastric cancer, esophageal cancer, pancreatic cancer, renal cell cancer and cervical cancer (large cell neuroendocrine histology) (20).

One of the more notable examples of abscopal effect in combined immune- and radiotherapy treatment was the report of a patient with metastatic melanoma treated with ipilimumab as maintenance therapy who suffered from back pain as a result of a paraspinal mass. Total dose of $28.5 \mathrm{~Gy}$ in three fractions was administered to a paraspinal mass. Four months after radiotherapy, CT scan showed not only paraspinal mass regression, but also regression of nonirradiated lesions in spleen and right hilar node. Stable, minimal disease persisted even after 10 months (21). Later report showed a complete regression of primary and metastatic lesions in a patient with metastatic melanoma treated with ipilimumab and radio- 
Table 1.

CLINICAL TRIALS USING CHECKPOINT INHIBITORS IN COMBINATION WITH RADIOTHERAPY [ADAPTED FROM 28]

\begin{tabular}{|c|c|c|c|c|}
\hline NCT Number & Status & Condition & Intervention & Characteristics \\
\hline NCT03042156 & Recruiting & $\begin{array}{l}\text { Advanced } \\
\text { cancer }\end{array}$ & $\begin{array}{l}\text { Radiotherapy } \\
\text { (palliative dose) }\end{array}$ & $\begin{array}{l}\text { Observational Model: Cohort } \\
\text { Outcome measures: } \\
\text { Number of patients developing grade } 3 \text { or higher toxicity; } \\
\text { In-field and out of field (abscopal) response; } \\
\text { The number of completed ESAS questionnaires; } \\
\text { Biomarkers analyses }\end{array}$ \\
\hline NCT03322384 & Recruiting & $\begin{array}{l}\text { Advanced solid } \\
\text { tumors } \\
\text { Lymphoma }\end{array}$ & $\begin{array}{l}\text { Epacadostat; } \\
\text { SD-101; } \\
\text { Radiotherapy }\end{array}$ & $\begin{array}{l}\text { Phase } 1 \\
\text { Phase } 2 \\
\text { Outcome Measures: } \\
\text { Incidence of adverse events; } \\
\text { Abscopal response rate; } \\
\text { Maximum tolerated dose } \\
\end{array}$ \\
\hline NCT04193696 & $\begin{array}{l}\text { Not yet } \\
\text { recruiting }\end{array}$ & $\begin{array}{l}\text { Advanced } \\
\text { hepatocellular } \\
\text { carcinoma }\end{array}$ & $\begin{array}{l}\text { Systemic anti-PD-1 } \\
\text { immunotherapy; } \\
\text { Radiotherapy }\end{array}$ & $\begin{array}{l}\text { Phase } 2 \\
\text { Outcome measures: } \\
\text { Objective response rate; } \\
\text { Overall survival; } \\
\text { Abscopal effects rate }\end{array}$ \\
\hline NCT03774732 & Recruiting & $\begin{array}{l}\text { Non-small cell } \\
\text { lung cancer }\end{array}$ & $\begin{array}{l}\text { Anti-PDL-1; } \\
\text { Radiotherapy }\end{array}$ & $\begin{array}{l}\text { Phase } 3 \\
\text { Outcome measures: } \\
\text { Overall survival; } \\
\text { Progression-free survival; } \\
\text { Tumor response; } \\
\text { Local and distant control; } \\
\text { Quality of life of the patients; } \\
\text { Acute/late toxicities }\end{array}$ \\
\hline NCT03453892 & Recruiting & $\begin{array}{l}\text { Metastatic } \\
\text { cancer }\end{array}$ & $\begin{array}{l}\text { Nivolumab; } \\
\text { Pembrolizumab; } \\
\text { Ipilimumab; } \\
\text { Radiotherapy }\end{array}$ & $\begin{array}{l}\text { Observational } \\
\text { Outcome measures: } \\
\text { Overall survival; } \\
\text { Progression-free survival; } \\
\text { Local and systemic response of detected metastases; } \\
\text { Adverse events; } \\
\text { Change of circulating immune cells of treated patients by deep } \\
\text { immunophenotyping }\end{array}$ \\
\hline NCT02406183 & Completed & Melanoma & $\begin{array}{l}\text { Ipilimumab; } \\
\text { Stereotactic body } \\
\text { radiotherapy (SBRT) }\end{array}$ & $\begin{array}{l}\text { Phase } 1 \\
\text { Outcome measures: } \\
\text { Overall survival; } \\
\text { Progression-free survival; } \\
\text { Maximal tolerated dose that is associated with dose-limiting } \\
\text { toxicity in } 25 \% \text { of patients; } \\
\text { Immunomonitoring; } \\
\text { Preliminary anti-tumor activity (using the immune related } \\
\text { response criteria) } \\
\text { following ipilimumab combined with escalating doses } \\
\text { of radiation }\end{array}$ \\
\hline NCT03277482 & Recruiting & $\begin{array}{l}\text { Recurrent } \\
\text { gynecological } \\
\text { cancer }\end{array}$ & $\begin{array}{l}\text { Durvalumab; } \\
\text { Tremelimumab; } \\
\text { Radiotherapy }\end{array}$ & $\begin{array}{l}\text { Phase } 1 \\
\text { Outcome Measures: } \\
\text { Maximum tolerated dose of combined treatment; } \\
\text { Abscopal response; } \\
\text { Local response; } \\
\text { Overall response; } \\
\text { Response duration; } \\
\text { Local control; } \\
\text { Progression-free survival; } \\
\text { Overall survival }\end{array}$ \\
\hline
\end{tabular}


Table 1.

CONTINUED

\begin{tabular}{|c|c|c|c|c|}
\hline NCT Number & Status & Condition & Intervention & Characteristics \\
\hline NCT03548428 & $\begin{array}{l}\text { Not yet } \\
\text { recruiting }\end{array}$ & Sarcoma & $\begin{array}{l}\text { Atezolizumab; } \\
\text { SBRT }\end{array}$ & $\begin{array}{l}\text { Phase } 2 \\
\text { Outcome Measures: } \\
\text { Progression-free survival (PFS) rate at } 6 \text { months; } \\
\text { PFS after radiotherapy/PFS during the previous line of treatment } \\
\text { ratio; } \\
\text { PFS by immune response criteria; } \\
\text { Overall survival; } \\
\text { Objective response rate; } \\
\text { Treatment toxicity; } \\
\text { Quality of life; } \\
\text { Rate of PET-CT at inclusion; } \\
\text { Treatment cost }\end{array}$ \\
\hline NCT03283605 & Recruiting & $\begin{array}{l}\text { Head and neck } \\
\text { squamous cell } \\
\text { carcinoma; } \\
\text { Metastatic } \\
\text { squamous cell } \\
\text { carcinoma }\end{array}$ & $\begin{array}{l}\text { SBRT; } \\
\text { Durvalumab; } \\
\text { Tremelimumab }\end{array}$ & $\begin{array}{l}\text { Phase 1; } \\
\text { Phase } 2 \\
\text { Outcome Measures: } \\
\text { Acute toxicity; } \\
\text { Abscopal events; } \\
\text { Local control; } \\
\text { Overall survival; } \\
\text { Progression-free survival }\end{array}$ \\
\hline NCT03539198 & Recruiting & $\begin{array}{l}\text { Head and neck } \\
\text { cancer }\end{array}$ & $\begin{array}{l}\text { Nivolumab; } \\
\text { Proton Stereotactic } \\
\text { Body Radiation } \\
\text { Therapy (SBRT) } \\
\text { (35-45 Gy in } 5 \\
\text { fractions) }\end{array}$ & $\begin{array}{l}\text { Observational } \\
\text { Outcome Measures: } \\
\text { Objective response rate; } \\
\text { Local control rate; } \\
\text { Overall survival; } \\
\text { Progression-free survival; } \\
\text { Time to progression; } \\
\text { New development of distant metastasis; } \\
\text { Quality of life; } \\
\text { Adverse effects; } \\
\text { Predictive and prognostic biomarkers }\end{array}$ \\
\hline NCT03509584 & $\begin{array}{l}\text { Not yet } \\
\text { recruiting }\end{array}$ & $\begin{array}{l}\text { Non-small cell } \\
\text { lung cancer }\end{array}$ & $\begin{array}{l}\text { Nivolumab; } \\
\text { Ipilimumab; } \\
\text { Radiotherapy } \\
\text { (hypofractionated) }\end{array}$ & $\begin{array}{l}\text { Phase } 1 \\
\text { Outcome Measures: } \\
\text { Incidence of immune related adverse events }\end{array}$ \\
\hline NCT04042506 & Recruiting & $\begin{array}{l}\text { Metastatic } \\
\text { melanoma }\end{array}$ & $\begin{array}{l}\text { Nivolumab; } \\
\text { SBRT }\end{array}$ & $\begin{array}{l}\text { Phase } 2 \\
\text { Outcome Measures: } \\
\text { Adverse events; } \\
\text { Clinical abscopal effect }\end{array}$ \\
\hline NCT03927898 & Recruiting & $\begin{array}{l}\text { Metastatic } \\
\text { colorectal } \\
\text { cancer }\end{array}$ & $\begin{array}{l}\text { Toripalimab; } \\
\text { SBRT }\end{array}$ & $\begin{array}{l}\text { Phase } 2 \\
\text { Outcome Measures: } \\
\text { Progression-free survival (PFS) at } 1 \text { year; } \\
\text { Grade } 3-5 \text { acute adverse events; } \\
\text { Objective response rate; } \\
\text { Local control rate at } 2 \text { years; } \\
\text { Overall survival at } 2 \text { years; } \\
\text { T cell clones in peripheral blood and T cell receptor repertoire; } \\
\text { PD-1, Ki-67 expression on T cell; } \\
\text { PD-L1 expression on exosomes in peripheral blood and on } \\
\text { circulating tumor cells }\end{array}$ \\
\hline NCT02992912 & Recruiting & $\begin{array}{l}\text { Metastatic } \\
\text { tumors }\end{array}$ & $\begin{array}{l}\text { Atezolizumab; } \\
\text { SBRT }\end{array}$ & $\begin{array}{l}\text { Phase } 2 \\
\text { Outcome Measures: } \\
\text { Progression-free survival }\end{array}$ \\
\hline
\end{tabular}


Table 1.

\section{CONTINUED}

\begin{tabular}{|c|c|c|c|c|}
\hline NCT Number & Status & Condition & Intervention & Characteristics \\
\hline NCT03176173 & Recruiting & $\begin{array}{l}\text { Stage IV } \\
\text { non-small cell } \\
\text { lung cancer }\end{array}$ & $\begin{array}{l}\text { Immunotherapy } \\
\text { (standard of care); } \\
\text { Image Guided } \\
\text { Radiation Therapy }\end{array}$ & $\begin{array}{l}\text { Phase } 2 \\
\text { Outcome Measures: } \\
\text { Progression-free survival; } \\
\text { Change in circulating tumor deoxyribonucleic acid levels } \\
\text { (by deep sequencing); } \\
\text { Change in levels of immune markers; } \\
\text { Incidence of acute and late grade } 3-5 \text { toxicity; } \\
\text { Overall survival }\end{array}$ \\
\hline NCT04221893 & $\begin{array}{l}\text { Not yet } \\
\text { recruiting }\end{array}$ & $\begin{array}{l}\text { Clinical stage IV } \\
\text { esophageal, } \\
\text { GEJ and gastric } \\
\text { cancer }\end{array}$ & Radiotherapy & $\begin{array}{l}\text { Phase: not applicable } \\
\text { Outcome Measures: } \\
\text { Overall response rate; } \\
\text { Progression-free survival; } \\
\text { Overall survival; } \\
\text { Tumor measurement change by RECIST or iRECIST; } \\
\text { Local control in radiated lesion(s); } \\
\text { Incidence of new metastatic lesions; } \\
\text { Frequency of grade } 3 \text { or higher adverse events; } \\
\text { Time to new systemic therapy }\end{array}$ \\
\hline NCT02888743 & $\begin{array}{l}\text { Active, not } \\
\text { recruiting }\end{array}$ & $\begin{array}{l}\text { Metastatic } \\
\text { colorectal } \\
\text { carcinoma; } \\
\text { Metastatic lung } \\
\text { non-small cell } \\
\text { carcinoma }\end{array}$ & $\begin{array}{l}\text { Durvalumab; } \\
\text { Tremelimumab; } \\
\text { Radiotherapy }\end{array}$ & $\begin{array}{l}\text { Phase } 2 \\
\text { Outcome Measures: } \\
\text { Incidence of adverse events; } \\
\text { Abscopal response rate; } \\
\text { Local control rate; } \\
\text { Overall response rate; } \\
\text { Progression-free survival; } \\
\text { Overall survival; } \\
\text { Objective response per immune-related response criteria; } \\
\text { Prognostic effect of PD-L1 expression; } \\
\text { Prognostic effect of T-cell infiltration }\end{array}$ \\
\hline NCT02587455 & Recruiting & $\begin{array}{l}\text { Thoracic } \\
\text { tumours }\end{array}$ & $\begin{array}{l}\text { Pembrolizumab; } \\
\text { Radiotherapy }\end{array}$ & $\begin{array}{l}\text { Phase } 1 \\
\text { Outcome Measures: } \\
\text { Maximum tolerated dose of pembrolizumab in combination } \\
\text { with radiotherapy; } \\
\text { Toxicity rate; } \\
\text { Progression-free survival rates at } 6 \text { and } 12 \text { months } \\
\text { (all and PDL-1 strong patients); } \\
\text { Overall survival rates at } 6 \text { and } 12 \text { months } \\
\text { (all and PDL-1 strong patients); } \\
\text { Duration of clinical benefit; } \\
\text { Response rate comparison between squamous and non- } \\
\text { squamous cancers }\end{array}$ \\
\hline NCT03085719 & Recruiting & $\begin{array}{l}\text { Head and neck } \\
\text { cancer }\end{array}$ & $\begin{array}{l}\text { Pembrolizumab; } \\
\text { Radiotherapy }\end{array}$ & $\begin{array}{l}\text { Phase } 2 \\
\text { Outcome Measures: } \\
\text { Overall response rate; } \\
\text { Local response determined using CT imaging; } \\
\text { Abscopal response determined using CT imaging; } \\
\text { Overall survival; } \\
\text { Progression-free survival; } \\
\text { Adverse events; } \\
\text { Objective response by immune related response criteria; } \\
\text { Clinical benefit rate }\end{array}$ \\
\hline
\end{tabular}

therapy. Total dose of 54 Gy was given in three fractions (22). In another clinical study, 34 patients with castration-resistant prostate cancer were treated with ipilimumab and palliative bone radiotherapy (one to three $8 \mathrm{~Gy}$ fractions). The re- sults showed complete clinical response in one patient, while six other had stable disease (23).

Hiniker et al. have shown $13.6 \%$ complete response rate in a prospective trial of combination ipilimumab plus radiotherapy in metastatic mela- 
noma patients (24), as opposed to $1.5 \%$ complete response rate reported in patients treated with ipilimumab only (25).

The efficacy of combined ipilimumab and radiotherapy treatment was also studied in a phase I study of 22 patients with metastatic melanoma. The results showed that $36 \%$ of patients had partial response or stable disease, while the rest had disease progression (26). It was later shown that the resistance to combination of radiotherapy and anti-CTLA4 treatment was partially linked to the upregulation of PD-L1 (27).

Currently, there are numerous ongoing clinical trials investigating combinations of radiation and immunotherapy. Some of the ongoing trials are shown in Table 1.

As can be noted, most of the trials are phase I and II, and aim to investigate the potential synergistic effects of radiation and immunotherapy in a myriad of cancers, including non-small cell lung cancer, head and neck cancer, colorectal cancer, esophageal, gastric and GEJ cancer, gynecological cancer, sarcoma and lymphoma. The most interesting, however, may be a phase III French NIRVANA-Lung trial, which is examining the feasibility and efficacy of the combination of anti-PD-L1 therapy and radiotherapy to advanced NSCLC. In this trial, 510 patients with stage IIIB-IV NSCLC are being randomized to receive immunotherapy (nivolumab, pembrolizumab or atezolizumab) or immunotherapy plus radiation (3D-CRT or SABR) to a total dose of $18 \mathrm{~Gy}$ in three fractions. Primary outcome of the trial is overall survival, which will be evaluated after a follow-up of 2 years. Local and distant disease control, tumor response, progression-free survival, quality of life and toxicities will be determined after a follow up of 6 months, 1 year and 2 years, respectively.

\section{THE OPTIMAL TIMING, DOSAGE AND FRACTIONATION OF RADIOTHERAPY}

Currently, the optimal parameters of radiotherapy to induce abscopal effect remain unknown. The dosage, fractionation and timing seem to vary across different studies.

Some preclinical studies seem to favor fewer fractions. One study on murine melanoma showed better response after a single fraction of $8 \mathrm{~Gy}$ than five fractions of $4 \mathrm{~Gy}(29)$, while the other favored two fractions of 7.5 Gy over a single fraction of 15 Gy (30).

Dewan et al. compared a single fraction of 20 Gy, three fractions of 8 Gy and five fractions of 6 Gy in combination with anti-CTLA4 antibody on a murine breast cancer, and reported that the fractionated regimes had better antitumor effect than a single dose of $20 \mathrm{~Gy}$ [31]. One retrospective analysis of 47 metastatic melanoma patients showed a significant correlation between abscopal effect and fractionated radiation, particularly with fractions equal and smaller than $3 \mathrm{~Gy}$ (32).

Currently, MD Anderson phase II trial (NCT02710253) is comparing different radiotherapy regimes in inducing response rates in metastatic patients who have been treated with immunotherapy within past 6 months. The regimes include $50 \mathrm{~Gy}$ in 4 fractions using stereotactic radiation or 60-70 Gy in 10 fractions, 20-30 Gy in 5 fractions, or 30-45 Gy in 10-15 fractions using conventional external-beam radiation. A phase I trial (NCT02406183), is comparing 24 Gy in 8 fractions using stereotactic radiation with $30 \mathrm{~Gy}$ in 10 fractions and $36 \mathrm{~Gy}$ in 12 fractions using conventional external-beam radiation; in combination with ipilimumab for metastatic melanoma.

The optimal sequencing of immunotherapy and radiotherapy is also controversial. While it seems that combination of ipilimumab and radiotherapy works best if given concurrently (31), durvalumab seems to be most effective if given after the chemoradiation (33).

One ongoing phase I study (NCT02826564) is evaluating the optimal sequencing of pembrolizumab and stereotactic body radiation in patients with urothelial carcinoma.

\section{RADIOIMMUNOTHERAPY TOXICITY}

There has been some concern that the combination of radiotherapy and immunotherapy may increase their respective toxicities. However, several clinical trials have shown that this is not the case (33-39). One trial in metastatic melanoma, however, showed higher rates of radiation necrosis when radiotherapy was combined with ipilimumab (30\% vs. $21 \%$ ), while the other reported higher rate of treatment-related pulmonary toxicity in comparison with pembrolizumab alone in treatment of non-small cell lung cancer (13\% vs. $1 \%)(39)$. 


\section{CONCLUSION}

Although abscopal effect is a phenomenon that has been known for many years, it has only recently been put under the spotlight, mostly due to the rapid advancements in immunotherapy. Although some of the underlying mechanisms behind this phenomenon have been understood, including its immunogenic nature, there are still several unknown variables needed to be determined in order to maximize the abscopal response in clinical setting. These include dose-fractionation regimes of radiotherapy, as well as determination of optimal treatment sequence. Increasing number of ongoing trials will hopefully give answers to these questions, allowing utilization of local radiotherapy in achieving systemic antitumor effects.

\section{REFERENCES}

1. Mole RH. Whole body irradiation; radiobiology or medicine? Br J Radiol. 1953;26:234-41.

2. Reynders K, Illidge T, Siva S, Chang JY, De Ruysscher D. The abscopal effect of local radiotherapy: Using immunotherapy to make a rare event clinically relevant. Cancer Treat Rev. 2015;41:503-10.

3. Juretic A. Cancer immunotherapy: Mechanisms of action. Libri Oncol. 2017;45(2-3): 38-42.

4. Radulović $P$, Krušlin B. Immunohistochemical expression of PD-L1 in solid tumors. Libri Oncol. 2017;45 (2-3): 43-45.

5. Dabelic N, Maric Brozic J, Djakovic N, Bolanca A. Advances in melanoma immunotherapy. Libri Oncol. 2017;45(2-3): 46-51.

6. Jakopovic M, Bitar L, Krpina K, Marusic D, Seiwerth F, Jankovic M, Samrzija M. Immunotherapy in the treatment of non-small cell lung cancer. Libri Oncol. 2017; 45(2-3): 60-64.

7. Bisof V. Novelties in immunotherapy of esophageal and stomac cancer. Libri Oncol. 2017;45(2-3): 65-68.

8. Yilmaz MT, Elmali A, Yazici G. Abscopal Effect, From Myth to Reality: From Radiation Oncologists' Perspective. Cureus. 2019;11(1):e3860.

9. Gameiro SR, Jammeh ML, Wattenberg MM, Tsang KY, Ferrone S, Hodge JW. Radiation-induced immunogenic modulation of tumor enhances antigen processing and calreticulin exposure, resulting in enhanced T-cell killing. Oncotarget. 2014;5(2):403-16.

10. Apetoh L, Ghiringhelli F, Tesniere A, Criollo A, Ortiz C, Lidereau $\mathrm{R}$, et al. The interaction between HMGB1 and TLR4 dictates the outcome of anticancer chemotherapy and radiotherapy. Immunol Rev. 2007;220: 47-59.

11. Ghiringhelli F, Apetoh L, Tesniere A, Aymeric L, Ma $\mathrm{Y}$, Ortiz C, et al. Activation of the NLRP3 inflamma- some in dendritic cells induces IL-1B-dependent adaptive immunity against tumors. Nat Med. 2009;15 (10):1170-8.

12. Hemmi H, Takeuchi O, Kawai T, Kaisho T, Sato S, Sanjo $\mathrm{H}$, et al. A Toll-like receptor recognizes bacterial DNA. Nature. 2000;408:740-5.

13. Reits EA, Hodge JW, Herberts CA, Groothuis TA, Chakraborty M, Wansley EK, et al. Radiation modulates the peptide repertoire, enhances MHC class I expression, and induces successful antitumor immunotherapy. J Exp Med. 2006;203:1259-71.

14. Lee Y, Auh SL, Wang Y, Burnette B, Wang Y, Meng Y, et al. Therapeutic effects of ablative radiation on local tumor require CD8 + T cells: Changing strategies for cancer treatment. Blood. 2009;114:589-95.

15. Demaria S, Ng B, Devitt ML, Babb JS, Kawashima N, Liebes $\mathrm{L}$, et al. Ionizing radiation inhibition of distant untreated tumors (abscopal effect) is immune mediated. Int J Radiat Oncol Biol Phys. 2004;58:862-70.

16. Dancea HC, Shareef MM, Ahmed MM. Role of Radiation-induced TGF-beta Signaling in Cancer Therapy. Mol Cell Pharmacol. 2009;1:44-56.

17. Kachikwu EL, Iwamoto KS, Liao YP, Demarco JJ, Agazaryan N, Economou JS, et al. Radiation enhances regulatory $\mathrm{T}$ cell representation. Int J Radiat Oncol Biol Phys. 2011;81:1128-35.

18. Vatner RE, Formenti SC. Myeloid-Derived Cells in Tumors: Effects of Radiation. Semin Radiat Oncol 2015; 25(1):18-27.

19. Beketic-Oreskovic L, Mikulandra M. Immunomodulatory effects of radiotherapy. Libr Oncol. 2017;45:72-7.

20. Dagoglu N, Karaman S, Caglar HB, Oral EN. Abscopal Effect of Radiotherapy in the Immunotherapy Era: Systematic Review of Reported Cases. Cureus. 2019 11(2):e4103.

21. Postow MA, Callahan MK, Barker CA, Yamada Y, Yuan J, Kitano S, et al. Immunologic correlates of the abscopal effect in a patient with melanoma. N Engl J Med. 2012;366:925-31.

22. Hiniker SM, Chen DS, Reddy S, Chang DT, Jones JC, Mollick JA, et al. A systemic complete response of metastatic melanoma to local radiation and immunotherapy. Transl Oncol. 2012;5:404-7.

23. Slovin SF, Higano CS, Hamid O, Tejwani S, Harzstark A, Alumkal JJ, et al. Ipilimumab alone or in combination with radiotherapy in metastatic castration-resistant prostate cancer: Results from an open-label, multicenter phase I/II study. Ann Oncol. 2013;24:1813-21.

24. Hiniker SM, Reddy SA, Maecker HT, Subrahmanyam PB, Rosenberg-Hasson Y, Swetter SM, et al. A Prospective Clinical Trial Combining Radiation Therapy With Systemic Immunotherapy in Metastatic Melanoma. Int J Radiat Oncol Biol Phys. 2016;96(3):578-88.

25. Hodi FS, Lee S, McDermott DF, Rao UN, Butterfield $\mathrm{LH}$, Tarhini AA, et al. Ipilimumab plus sargramostim vs ipilimumab alone for treatment of metastatic melanoma: A randomized clinical trial. JAMA. 2014;312 (17):1744-53. 
26. Victor CT-S, Rech AJ, Maity A, Rengan R, Pauken KE, Stelekati E, et al. Radiation and dual checkpoint blockade activate non-redundant immune mechanisms in cancer. Nature. 2015;520:373-7.

27. Ngiow SF, McArthur GA, Smyth MJ. Radiotherapy complements immune checkpoint blockade. Cancer Cell. 2015;27:437-8.

28. ClinicalTrials.gov [Internet]. Bethesda (MD): National Library of Medicine (US). 2000 Feb 29. [cited 2020 Jan 22]; Available from: https://clinicaltrials.gov/.

29. Shen RN, Hornback NB, Shidnia H, Lu L, Montebello JF, Brahmi Z. A Comparison of Lung Metastases and Natural Killer Cell Activity in Daily Fractions and Weekly Fractions of Radiation Therapy on Murine B16 a Melanoma. Radiat Res. 1988; 114(2):354-60.

30. Schaue D, Ratikan JA, Iwamoto KS, McBride WH. Maximizing tumor immunity with fractionated radiation. Int J Radiat Oncol Biol Phys. 2012; 83(4):1306-10.

31. Dewan MZ, Galloway AE, Kawashima N, Dewyngaert JK, Babb JS, Formenti SC, et al. Fractionated but not single-dose radiotherapy induces an immune-mediated abscopal effect when combined with anti-CTLA-4 antibody. Clin Cancer Res. 2009;15(17):5379-88.

32. Chandra RA, Wilhite TJ, Balboni TA, Alexander BM, Spektor A, Ott PA, et al. A systematic evaluation of abscopal responses following radiotherapy in patients with metastatic melanoma treated with ipilimumab. Oncoimmunology. 2015; 4(11):e1046028.

33. Antonia SJ, Villegas A, Daniel D, Vicente D, Murakami $S$, Hui R, et al. Durvalumab after chemoradiotherapy in stage III non-small-cell lung cancer. N Engl J Med. 2017; 379(24):2342-2350.

34. Kiess AP, Wolchok JD, Barker CA, Postow MA, Tabar $\mathrm{V}$, Huse JT, et al. Stereotactic radiosurgery for melanoma brain metastases in patients receiving ipilimumab: Safety profile and efficacy of combined treatment. Int J Radiat Oncol Biol Phys. 2015; 92(2):368-75.

35. Silk AW, Bassetti MF, West BT, Tsien CI, Lao CD. Ipilimumab and radiation therapy for melanoma brain metastases. Cancer Med. 2013; 2(6):899-906.

36. Tazi K, Hathaway A, Chiuzan C, Shirai K. Survival of melanoma patients with brain metastases treated with ipilimumab and stereotactic radiosurgery. Cancer Med. 2015; 4(1):1-6.

37. Qin R, Olson A, Singh B, Thomas S, Wolf S, Bhavsar NA, et al. Safety and Efficacy of Radiation Therapy in Advanced Melanoma Patients Treated With Ipilimumab. Int J Radiat Oncol Biol Phys. 2016; 96(1):72-7.

38. Ahmed KA, Stallworth DG, Kim Y, Johnstone PAS, Harrison LB, Caudell JJ, et al. Clinical outcomes of melanoma brain metastases treated with stereotactic radiation and anti-PD-1 therapy. Ann Oncol. 2016; 27(3):434-41.

39. Shaverdian N, Lisberg AE, Bornazyan K, Veruttipong D, Goldman JW, Formenti SC, et al. Previous radiotherapy and the clinical activity and toxicity of pembrolizumab in the treatment of non-small-cell lung cancer: a secondary analysis of the KEYNOTE-001 phase 1 trial. Lancet Oncol. 2017; 18(7):895-903.

Sažetak

\title{
APSKOPALNI UČINAK RADIOTERAPIJE: STARI KONCEPT U NOVOM DOBU
}

\author{
M. Mikulandra, I. Andrašek and L. Beketić-Orešković
}

Apskopalni učinak je fenomen koji opisuje sustavni antitumorski odgovor koji može nastati kao rezultat lokalizirane radioterapije. Premda su sporadični slučajevi prijavljivani još od 1960-tih godina, njihov je broj značajno porastao u eri imunoterapije. Čini se da imunoterapija stimulira imunogenične učinke radioterapije, pojačavajući na taj način sistemski antitumorski odgovor. Iako je kombinacija radioterapije i imunoterapije obećavajuća strategija u liječenju metastatskih tumora, još uvijek nemamo odgovore na brojna pitanja vezana za optimalni protokol liječenja. Sve veći broj istraživanja koja su u tijeku vjerojatno će dati odgovore ta neriješena pitanja, što će omogućiti korištenje ove strategije u sustavnom liječenju raka.

KLJUČNE RIJEČI: apskopalni učinak, radioterapija, imunoterapija 